man hair-follicle growth. Proc Natl Acad Sci U S A 2013; 110:19679-19688.

6. Seo $\mathrm{CH}$, Kwack MH, Lee SH, Kim MK, Kim JC, Sung YK. Poor capability of 3D-cultured adipose-derived stem cells to induce hair follicles in contrast to 3D-cultured dermal papilla cells. Ann Dermatol 2016;28:662-665.

7. Legrand JMD, Roy E, Ellis JJ, Francois M, Brooks AJ, Khosrotehrani K. STAT5 activation in the dermal papilla is important for hair follicle growth phase induction. J Invest Dermatol 2016;136:1781-1791.

8. Harel S, Higgins CA, Cerise JE, Dai Z, Chen JC, Clynes R, et al.
Pharmacologic inhibition of JAK-STAT signaling promotes hair growth. Sci Adv 2015;1:e1500973.

9. Zheng Y, Du X, Wang W, Boucher M, Parimoo S, Stenn K. Organogenesis from dissociated cells: generation of mature cycling hair follicles from skin-derived cells. J Invest Dermatol 2005; 124:867-876.

10. McElwee KJ, Kissling S, Wenzel E, Huth A, Hoffmann R. Cultured peribulbar dermal sheath cells can induce hair follicle development and contribute to the dermal sheath and dermal papilla. J Invest Dermatol 2003;121:1267-1275.

\title{
Long-Term Prognosis of Alopecia Areata in Children and Adolescents
}

\author{
Yong Hyun Jang, Dong Hyuk Eun, Do Won Kim \\ Department of Dermatology, School of Medicine, Kyungpook National University, Daegu, Korea
}

\section{Dear Editor:}

The prognosis of alopecia areata (AA) during childhood may be worse in comparison to cases involving adult patients ${ }^{1,2}$. However, there is no concrete evidence for this assumption because it is based on a small number of studies on Asian subjects with insufficient long-term follow-up data $^{3,4}$. Disease progression in children with AA is also more difficult to predict in comparison to adults. It is possible that prognosis is worse because disease progression in children with mild AA is not necessarily better ${ }^{2}$. When AA progresses to alopecia totalis (AT) or alopecia universalis (AU), long-term prognosis with respect to full recovery is generally reported at a frequency of less than $10 \%{ }^{5}$. However, the data for this result is outdated and was reported in the 1950s, thereby making evidence unreliable.
Recently, we evaluated the long-term prognosis of patients with AT or AU and found that it is better than previously thought ${ }^{6}$. Long-term outcome evaluation of patients with $\mathrm{AA}$ is important. Because $\mathrm{AA}$ is associated with frequent recurrence, it is difficult to determine whether complete recovery has occurred when AA progresses to more severe conditions. Our previous study suggests that at least 5 years of follow-up observation is required to predict the long-term prognosis of patients with $\mathrm{AA}^{7}$.

In this study, we investigated the long-term prognosis ( $>10$ years) of children and adolescents ( $\leq 19$ years old) with AA. Among 140 patients with pediatric AA from our outpatient database, 75 who were available for follow-up observations for long-term prognosis via their medical records and phone surveys were included. This study was

\footnotetext{
Received March 9, 2018, Revised March 15, 2018, Accepted for publication March 22, 2018
}

Corresponding author: Yong Hyun Jang, Department of Dermatology, Kyungpook National University Hospital, 130 Dongdeok-ro, Jung-gu, Daegu 41944, Korea. Tel: 82-53-420-5838, Fax: 82-53-426-0770, E-mail: yhjang@knu.ac.kr ORCID: https://orcid.org/0000-0003-1706-007X

This is an Open Access article distributed under the terms of the Creative Commons Attribution Non-Commercial License (http://creativecommons.org/ licenses/by-nc/4.0) which permits unrestricted non-commercial use, distribution, and reproduction in any medium, provided the original work is properly cited.

Copyright (C) The Korean Dermatological Association and The Korean Society for Investigative Dermatology 
approved by the Institutional Review Board of Kyungpook National University Hospital (KNUH 2018-01-001). Overall, a total of 75 patients including 41 males and 34 females were enrolled in the study. The mean age of onset was 8.2 years and the duration of hair loss from the time of onset was an average of 13.5 years. At initial visit, 27 patients had S1 ( $<25 \%$ hair loss), 14 patients had S2 (25\% 49\% hair loss), 5 patients had S3 (50\% 74\% hair loss), 9 patients had S4 (75\% 99\% hair loss), and 20 patients had AT/AU (Table 1). Full hair regrowth was observed in approximately $34.7 \%$ of patients, and no hair regrowth or aggravation was observed in approximately $32.0 \%$. In S1 and S2, complete hair regrowth was observed in approximately $50 \%$ of patients, and no hair regrowth or aggravation in approximately $20 \%$. Complete hair regrowth was found in 2 patients with AT/AU. Therapeutic modalities for AA depend on patient age ${ }^{8}$. In those younger than 10 years, intralesional corticosteroids and topical immunotherapy are avoided. Those older than 10 years are treated with the same protocols as adults. Therefore, we conducted a subgroup analysis based on the age 10 . The results for patients younger than 10 years and patients aged 10 19 years were not significantly different; however, the rates of no hair regrowth or aggravation for S1 and S2 were higher in patients younger than 10 years (Table 2 ).

We found that patients had less favorable prognosis when the duration of hair loss was longer, and when they had a longer period from disease onset to hospital visit. The presence or absence of atopic disease did not significantly affect prognosis, nor did family history or nail involvement (data not shown). Complete hair regrowth was more frequent when topical agents were used. In particular, complete hair regrowth was less when diphenylcyclopropenone immunotherapy and systemic immunosuppressants were used; however, this was because of the difference in the severity of the condition in patients who participated in the treatment (Table 2).

The natural history of $\mathrm{AA}$ is difficult to predict and the prognosis of children may be worse than that of adults ${ }^{1-4}$. It is also known that no treatment can affect the course of $\mathrm{AA}^{9}$. Unlike atopic dermatitis or psoriasis, the extent of disease does not always reflect disease activity or progression in AA. AA in a small alopecic area can progress to AT or AU if the activity of alopecic lesions is high ${ }^{10}$. This supports the clinical significance of the long-term outcome of AA, especially in children. However, the longterm prognosis of AA that begin in childhood is uncertain. Tosti et al. ${ }^{2}$ reported that long-term follow-up study of 191 patients with AA. They included 39 patients were 14 years of age or younger at presentation. Of 24 children with S2 disease, only 3 recovered completely, while 6 developed AT and $6 \mathrm{AU}$; the others maintained S1 or S2 disease, with varying severity. They showed that long-term prognosis for childhood AA in general is poorer than in adults. Compared to this study, we found that the rate of no change or aggravation is lower. This is may be due to the relatively large number of S1 patients in our study.

Limitations include the evaluation of hair loss condition via chart review and phone survey, the limited number of subjects included, and selection bias.

In this study, we found that $34.7 \%$ of pediatric and adolescent patients with AA had full-hair regrowth, and $32.0 \%$ had no hair regrowth or aggravation among the 75 pediatric and adolescent patients with AA. Our results suggest that the severity of the first visit is associated with longterm prognosis. In case of children, if the hair loss area is mild but the activity is high, disease may become worse. Therefore, the extent and disease activity should both be taken into consideration.

Table 1. Demographic and clinical characteristics of children and adolescents with alopecia areata

\begin{tabular}{|c|c|c|c|c|c|c|c|}
\hline Characteristic & S1 $\quad(n=27)$ & S2 $(n=14)$ & S3 $(n=5)$ & $\mathrm{S} 4(\mathrm{n}=9)$ & AT $(n=8)$ & $\mathrm{AU}(\mathrm{n}=12)$ & Total $(n=75)$ \\
\hline \multicolumn{8}{|l|}{ Sex (patient no.) } \\
\hline Male & 15 & 8 & 2 & 5 & 4 & 7 & 41 \\
\hline Female & 12 & 6 & 3 & 4 & 4 & 5 & 34 \\
\hline \multicolumn{8}{|l|}{ Age (yr) } \\
\hline Onset & $7.2 \pm 4.1$ & $9.6 \pm 4.9$ & $5.0 \pm 5.2$ & $11.9 \pm 4.1$ & $7.9 \pm 4.9$ & $7.6 \pm 5.3$ & $8.2 \pm 4.8$ \\
\hline Initial visit & $7.7 \pm 4.3$ & $10.2 \pm 4.8$ & $7.2 \pm 5.5$ & $13.6 \pm 3.0$ & $10.6 \pm 6.1$ & $12.0 \pm 5.9$ & $9.9 \pm 5.1$ \\
\hline Current & $18.2 \pm 4.5$ & $21.6 \pm 5.1$ & $17.9 \pm 4.0$ & $25.2 \pm 4.5$ & $25.5 \pm 5.8$ & $25.9 \pm 6.5$ & $21.7 \pm 6.0$ \\
\hline \multicolumn{8}{|l|}{ Duration (yr) } \\
\hline Onset of alopecia & $11.0 \pm 3.3$ & $12.0 \pm 3.1$ & $12.9 \pm 1.7$ & $13.3 \pm 3.3$ & $17.6 \pm 1.9$ & $18.3 \pm 7.0$ & $13.5 \pm 4.8$ \\
\hline First visit & $10.4 \pm 2.4$ & $11.4 \pm 3.0$ & $10.7 \pm 2.4$ & $11.6 \pm 3.1$ & $14.9 \pm 1.7$ & $13.9 \pm 3.1$ & $11.8 \pm 3.0$ \\
\hline
\end{tabular}

Values are presented as number or mean \pm standard deviation. S1: $<25 \%$ hair loss, S2: $25 \% \sim 49 \%$ hair loss, S3: $50 \% \sim 74 \%$ hair loss, S4: $75 \% \sim 99 \%$ hair loss, AT: alopecia totalis, AU: alopecia universalis. 
Table 2. Long-term outcomes of patients with AA in children and adolescents $(n=75)$, based on known prognostic factors and main therapeutic modalities

\begin{tabular}{|c|c|c|c|c|c|c|}
\hline \multirow{2}{*}{ Prognostic factors } & \multirow{2}{*}{$\begin{array}{c}\text { No hair regrowth } \\
\text { or aggravation }\end{array}$} & \multicolumn{4}{|c|}{ Partial hair regrowth } & \multirow{2}{*}{$\begin{array}{l}\text { Complete hair } \\
\text { regrowth }\end{array}$} \\
\hline & & $<10 \%$ & $10 \% \sim 49 \%$ & $50 \% \sim 89 \%$ & $\geq 90 \%$ & \\
\hline \multicolumn{7}{|l|}{ Clinical type of $\mathrm{AA}$} \\
\hline S1 $(n=27)$ & $5(18.5)$ & - & $2(7.4)$ & $3(11.1)$ & $3(11.1)$ & $14(51.9)$ \\
\hline S2 $(n=14)$ & $3(21.4)$ & $1(7.1)$ & $1(7.1)$ & - & $2(14.3)$ & $7(50.0)$ \\
\hline S3 $(n=5)$ & $1(20.0)$ & - & - & - & $3(60.0)$ & $1(20.0)$ \\
\hline $\mathrm{S} 4(\mathrm{n}=9)$ & $4(44.4)$ & $1(11.1)$ & $2(22.2)$ & - & - & $2(22.2)$ \\
\hline AT $(n=8)$ & $3(37.5)$ & - & $2(25.0)$ & $1(12.5)$ & $1(12.5)$ & $1(12.5)$ \\
\hline $\mathrm{AU}(\mathrm{n}=12)$ & $8(66.7)$ & $1(8.3)$ & $1(8.3)$ & $1(8.3)$ & - & $1(8.3)$ \\
\hline Total $(n=75)$ & $24(32.0)$ & $3(4.0)$ & $8(10.7)$ & $5(6.7)$ & $9(12.0)$ & $26(34.7)$ \\
\hline \multicolumn{7}{|c|}{ Clinical type of $\mathrm{AA}$ (patients with onset earlier than 10 years of age) } \\
\hline S1 $(n=21)$ & $4(19.0)$ & - & $2(9.5)$ & $3(14.3)$ & $2(9.5)$ & $10(47.6)$ \\
\hline$S 2(n=7)$ & $2(28.6)$ & $1(14.3)$ & - & - & - & $4(57.1)$ \\
\hline S3 $(n=4)$ & $1(25.0)$ & - & - & - & $2(50.0)$ & $1(25.0)$ \\
\hline $\mathrm{S} 4(\mathrm{n}=2)$ & - & - & $1(50.0)$ & - & - & $1(50.0)$ \\
\hline AT $(n=4)$ & $1(25.0)$ & - & $2(50.0)$ & - & $1(25.0)$ & - \\
\hline $\mathrm{AU}(\mathrm{n}=8)$ & $5(62.5)$ & $1(12.5)$ & $1(12.5)$ & $1(12.5)$ & - & - \\
\hline Total $(n=46)$ & $13(28.3)$ & $2(4.3)$ & $6(13.0)$ & $4(8.7)$ & $5(10.9)$ & $16(34.8)$ \\
\hline \multicolumn{7}{|c|}{ Clinical type of AA (patients with onset aged $10 \sim 19$ years) } \\
\hline$S 1(n=6)$ & $1(16.7)$ & - & - & - & $1(16.7)$ & $4(66.7)$ \\
\hline $\mathrm{S} 2(\mathrm{n}=7)$ & $1(14.3)$ & - & $1(14.3)$ & - & $2(28.6)$ & $3(42.9)$ \\
\hline S3 $(n=1)$ & - & - & - & - & $1(100.0)$ & - \\
\hline$S 4(n=7)$ & $4(57.1)$ & $1(14.3)$ & $1(14.3)$ & - & - & $1(14.3)$ \\
\hline AT $(n=4)$ & $2(50.0)$ & - & - & $1(25.0)$ & - & $1(25.0)$ \\
\hline $\mathrm{AU}(\mathrm{n}=4)$ & $3(75.0)$ & - & - & - & - & $1(25.0)$ \\
\hline Total $(n=29)$ & $11(37.9)$ & $1(3.4)$ & $2(6.9)$ & $1(3.4)$ & $4(13.8)$ & $10(34.5)$ \\
\hline \multicolumn{7}{|l|}{ The period from onset of alopecia } \\
\hline $8 \sim 12$ yr $(n=40)$ & $7(17.5)$ & $1(2.5)$ & $4(10.0)$ & $4(10.0)$ & $6(15.0)$ & $18(45.0)$ \\
\hline $13 \sim 17$ yr $(n=19)$ & $6(31.6)$ & - & $3(15.8)$ & $1(5.3)$ & $2(10.5)$ & 7 (36.8) \\
\hline$\geq 18$ yr $(n=16)$ & $11(68.8)$ & $2(12.5)$ & $1(6.3)$ & - & $1(6.3)$ & $1(6.3)$ \\
\hline Total $(n=75)$ & $24(32.0)$ & $3(4.0)$ & $8(10.7)$ & $5(6.7)$ & $9(12.0)$ & $26(34.7)$ \\
\hline \multicolumn{7}{|c|}{ Duration of the disease at time of first visit } \\
\hline$<3$ mo $(\mathrm{n}=25)$ & $5(20.0)$ & $1(4.0)$ & $2(8.0)$ & $2(8.0)$ & $2(8.0)$ & $13(52.0)$ \\
\hline $3 \sim 1 \mathrm{mo}(\mathrm{n}=26)$ & $8(30.8)$ & $1(3.8)$ & $5(19.2)$ & $1(3.8)$ & $2(7.7)$ & 9 (34.6) \\
\hline $12 \sim 24$ mo $(n=11)$ & $5(45.5)$ & - & - & - & $2(18.2)$ & $4(36.4)$ \\
\hline $2 \sim 5 \mathrm{yr}(\mathrm{n}=5)$ & $1(20.0)$ & - & - & $2(40.0)$ & $2(40.0)$ & - \\
\hline$>5 \mathrm{yr}(\mathrm{n}=8)$ & $5(62.5)$ & $1(12.5)$ & $1(12.5)$ & $1(12.5)$ & - & - \\
\hline Total $(n=75)$ & $24(32.0)$ & $3(4.0)$ & $8(10.7)$ & $5(6.7)$ & $9(12.0)$ & $26(34.7)$ \\
\hline \multicolumn{7}{|l|}{ Concomitant atopic diseases } \\
\hline Yes $(n=30)$ & $8(26.7)$ & $1(3.3)$ & $4(13.3)$ & $3(10.0)$ & $4(13.3)$ & $10(33.3)$ \\
\hline No $(n=45)$ & $16(35.6)$ & $2(4.4)$ & $4(8.9)$ & $2(4.4)$ & $5(11.1)$ & $16(35.6)$ \\
\hline Total $(\mathrm{n}=75)$ & $24(32.0)$ & $3(4.0)$ & $8(10.7)$ & $5(6.7)$ & $9(12.0)$ & $26(34.7)$ \\
\hline \multicolumn{7}{|l|}{ Main therapeutic modalities } \\
\hline Diphenylcyclopropenone $(n=15)$ & $9(60.0)$ & - & $3(20.0)$ & $1(6.7)$ & $1(6.7)$ & $1(6.7)$ \\
\hline Systemic immunosuppressants $(n=5)$ & $2(40.0)$ & - & $1(20.0)$ & - & $1(20.0)$ & $1(20.0)$ \\
\hline Topicals $(n=31)$ & $3(9.7)$ & $1(3.2)$ & $2(6.5)$ & $2(6.5)$ & $4(12.9)$ & $19(61.3)$ \\
\hline Combined and/or intercurrent $(\mathrm{n}=16)$ & $8(50.0)$ & $2(12.5)$ & $1(6.3)$ & $1(6.3)$ & $1(6.3)$ & $3(18.8)$ \\
\hline Others $(n=8)$ & $2(25.0)$ & - & $1(12.5)$ & $1(12.5)$ & $2(25.0)$ & $2(25.0)$ \\
\hline Total $(n=75)$ & $24(32.0)$ & $3(4.0)$ & $8(10.7)$ & $5(6.7)$ & $9(12.0)$ & $26(34.7)$ \\
\hline
\end{tabular}

Values are presented as number (\%). S1: $<25 \%$ hair loss, S2: $25 \% \sim 49 \%$ hair loss, S3: $50 \% \sim 74 \%$ hair loss, S4: $75 \% \sim 99 \%$ hair loss, AA: alopecia areata, AT: alopecia totalis, AU: alopecia universalis. 


\section{ACKNOWLEDGMENT}

This research was supported by Kyungpook National University Research Fund, 2017.

\section{CONFLICTS OF INTEREST}

The authors have nothing to disclose.

\section{ORCID}

Yong Hyun Jang, https://orcid.org/0000-0003-1706-007X

Dong Hyuk Eun, https://orcid.org/0000-0003-4044-0679

Do Won Kim, https://orcid.org/0000-0001-6632-1374

\section{REFERENCES}

1. Alkhalifah A, Alsantali A, Wang E, McElwee KJ, Shapiro J. Alopecia areata update: part I. clinical picture, histopathology, and pathogenesis. J Am Acad Dermatol 2010;62: 177-188, quiz 189-190.

2. Tosti A, Bellavista S, lorizzo M. Alopecia areata: a long term follow-up study of 191 patients. J Am Acad Dermatol 2006; 55:438-441.

3. Tan E, Tay YK, Giam YC. A clinical study of childhood alopecia areata in Singapore. Pediatr Dermatol 2002;19:298-301.
4. Xiao FL, Yang S, Liu JB, He PP, Yang J, Cui Y, et al. The epidemiology of childhood alopecia areata in China: a study of 226 patients. Pediatr Dermatol 2006;23:13-18.

5. Walker SA, Rothman S. A statistical study and consideration of endocrine influences. J Invest Dermatol 1950;14:403-413.

6. Jang YH, Hong NS, Moon SY, Eun DH, Lee WK, Chi SG, et al. Long-term prognosis of alopecia totalis and alopecia universalis: a longitudinal study with more than 10 years of follow-up: better than reported. Dermatology 2017;233:250256.

7. Lee JC, Kim HY, Kim HJ, Kim BS, Lee WJ, Lee SJ, et al. Long term follow-up study of corticosteroid-treated patients with alopecia areata. Korean J Dermatol 2008;46:465-472.

8. Otberg N, Shapiro J. Hair growth disorders. In: Goldsmith LA, Katz SI, Gilchrest BA, Paller AS, Leffell DJ, Wolff K, editors. Fitzpatrick's dermatology in general medicine. 8th ed. New York: McGraw-Hill, 2012:993.

9. MacDonald Hull SP, Wood ML, Hutchinson PE, Sladden M, Messenger AG; British Association of Dermatologists. Guidelines for the management of alopecia areata. $\mathrm{Br} J$ Dermatol 2003; 149:692-699.

10. Jang YH, Moon SY, Lee WJ, Lee SJ, Lee WK, Park BC, et al. Alopecia areata progression index, a scoring system for evaluating overall hair loss activity in alopecia areata patients with pigmented hair: a development and reliability assessment. Dermatology 2016;232:143-149. 